\title{
AKTYWNOŚĆ SPOŁECZNOŚCI WIEJSKIEJ W RAMACH FUNKCJONOWANIA LOKALNYCH GRUP DZIALANIA W WOJEWÓDZTWIE ŚWIĘTOKRZYSKIM
}

\begin{abstract}
Zarys treści: W procesie rozwoju obszarów wiejskich istotną rolę odgrywają organizacje pozarządowe i stowarzyszenia lokalne. Charakterystycznym przykładem takich inicjatyw są Lokalne Grupy Działania. Główną przesłanką działania LGD jest aktywizacja środowisk wiejskich w kierunku kształtowania rozwoju, poprzez sformułowanie potrzeb społeczności. Celem pracy jest ocena aktywności mieszkańców wsi woj. świętokrzyskiego w ramach inicjatyw podejmowanych przez wybrane LGD. W badaniu wykorzystano źródła wtórne dokonując kwerendy dostępnych materiałów: dokumentów stowarzyszeniowych, strategii, danych GUS, informacji z bazy Krajowej Sieci Obszarów Wiejskich 2014-2020. Aktywność społeczności lokalnej zbadano na podstawie informacji o zrealizowanych działaniach w latach 2014-2017, które zostały zamieszczone przez obrane LGD na portalu społecznościowym Facebook. Zakres czasowy analiz objął lata 2007-2017. W badaniu uwzględniono 5 LGD, które mają siedziby na terenie woj. świętokrzyskiego i są zlokalizowane w różnych jego częściach. Tereny objęte działaniem tych partnerstw są zróżnicowane pod względem warunków środowiskowych i charakteru pełnionych funkcji gospodarczych.
\end{abstract}

Słowa kluczowe: Lokalne Grupy Działania, obszary wiejskie, aktywność społeczna, walory przyrodnicze, potencjał turystyczny, dziedzictwo kulturowe.

\section{Wprowadzenie}

W rozwoju obszarów wiejskich największe znaczenie odgrywają lokalne inicjatywy. Wraz z odrodzeniem się struktur samorządowych rozpoczęła się tzw. „oddolna droga rozwoju" wsi.

Z dotychczasowych przykładów zagranicznych i krajowych wynika, że najwłaściwszą receptą na problemy towarzyszące wielofunkcyjnemu rozwojowi wsi jest włączenie w ten proces lokalnej ludności. Przykładem takich działań są inicjatywy powstające w „Programie odnowy wsi”. Funkcjonuje on w Polsce od 
końca lat 90. ubiegłego wieku. Jego istotą jest udostępnianie środków finansowych na rzecz rozwiązywania problemów społeczności lokalnych, które wcześniej określone zostały w planie rozwoju, przy inicjatywie oraz zaangażowaniu mieszkańców (Jeziorska-Biel 2014). Warto zaznaczyć, że w polskich warunkach program realizuje bardzo ważny cel, jakim jest budowa społeczności samorządowych, przy ograniczaniu negatywnego wpływu wielu społecznych zachowań jako konsekwencji oddziaływania zarówno poprzedniego systemu politycznego, jak i usieciowienia relacji w społeczeństwie konsumpcyjnym (Wójcik 2010).

Priorytetowe znaczenie w rozwoju obszarów wiejskich ma podejście LEADER, które zostało zapoczątkowane w 1991 roku. W okresie programowania 2007-2013 stało się ono obligatoryjną częścią programów rozwoju wsi każdego z państw członkowskich Unii Europejskiej (UE). Celem tej metody jest aktywizacja mieszkańców obszarów wiejskich poprzez budowanie potencjału społecznego na wsi. W Polsce w ramach Osi 4 Programu Rozwoju Obszarów Wiejskich (PROW) na lata 2007-2013, która dotyczy programu LEADER, podejmowano 3 główne działania: „Wdrażanie lokalnych strategii rozwoju” (LSR), „Wdrażanie projektów współpracy”, „Funkcjonowanie lokalnej grupy działania, nabywanie umiejętności i aktywizacja”. Zawarte w nich zadania budowy aktywności mieszkańców były wdrażane (autorstwo i zarządzanie strategią rozwoju) i realizowane (rola beneficjenta) za pośrednictwem Lokalnych Grup Działania (LGD). W ich skład mogą wchodzić przedstawiciele władz samorządowych itp. (sektor publiczny), organizacji pozarządowych (sektor społeczny) i miejscowych przedsiębiorców (sektor gospodarczy), często z terenów kilku gmin (Pałka 2014). W tych publiczno-prywatnych partnerstwach zaangażowanie sektora publicznego nie może przekroczyć połowy głosów w głównych organach decyzyjnych (Kamiński 2006). Natomiast identyfikacja obszaru działalności LGD oparta jest na trzech wyznacznikach: liczba mieszkańców stałych zawierająca się w przedziale 10-150 tys. osób; utrzymanie przestrzennej spójności dla całych gmin, bez wyłączania miast w gminach miejsko-wiejskich, gdzie liczba ludności zameldowanej na pobyt stały wynosi maksymalnie 20 tys.; występowanie spójnych uwarunkowań historycznych, kulturowych, przyrodniczych i społeczno-gospodarczych ${ }^{1}$ (Kołodziejczak 2011). Przedsięwzięcia LGD, wymierzone na rozwój przestrzeni lokalnej o takich cechach, wymagały oczywiście partycypacji znacznych nakładów finansowych ze strony wspólnoty europejskiej.

W dalszym ciągu te trójsektorowe grupy działania mogą liczyć na współfinansowanie ze środków UE. W obecnej perspektywie związanej z PROW na lata 2014-2020 nastąpiła kontynuacja założeń LEADER jako rozwoju lokalnego kierowanego przez społeczność (RLKS). Jest to jedno z 14 działań zaplanowanych na trwający okres programowania (Program... 2014).

${ }^{1}$ To spójność stanowiąca podobieństwo lub jednorodność gmin wchodzących w skład obszaru albo istnienie takiego elementu, który występuje w każdej gminie. 
Przejawem aktywności społecznej mogą być różne formy działalności jednostek, grup społecznych i organizacji, mające na celu urzeczywistnienie naturalnych indywidualnych potrzeb. Należą do nich: kampanie, programy i wiece, organizowanie różnego rodzaju inicjatyw, które cechuje otwartość i pomysłowość. Jednym z przykładów takich przedsięwzięć są właśnie LGD.

Celem niniejszego opracowania jest ocena aktywności mieszkańców wsi województwa świętokrzyskiego w ramach inicjatyw podejmowanych przez wybrane Lokalne Grupy Działania. Przeanalizowano zatem 5 LGD mających siedziby na terenie woj. świętokrzyskiego. Podstawą doboru grup do analizy była lokalizacja w różnych częściach województwa. W dodatku obszary zajmowane przez poszczególne LGD są zróżnicowane pod względem środowiska przyrodniczego i pełnionych funkcji gospodarczych. W ogólnym zarysie głównymi ich wyróżnikami są: czyste środowisko, walory krajobrazowo-przyrodnicze, typowa funkcja rolnicza, bogate dziedzictwo kulturowe czy wielofunkcyjność.

W badaniu wykorzystano źródła wtórne, dokonując kwerendy dostępnych materiałów, obejmujących: dokumenty stowarzyszeniowe (statuty LGD), opracowania strategiczne (Lokalne Strategie Rozwoju, Strategie Rozwoju Lokalnego Kierowanego przez Społeczność), dane statystyczne Banku Danych Lokalnych (BDL) GUS, informacje pozyskane z bazy Krajowej Sieci Obszarów Wiejskich (KSOW) zgodnej z PROW 2014-2020. Sposoby aktywności społecznej przeanalizowano na podstawie informacji na temat zrealizowanych przedsięwzięć w latach 2014-2017, które zostały zamieszczone przez obrane LGD na portalu społecznościowym Facebook. Zakres czasowy analizy dotyczył lat 2007-2017.

\section{Charakterystyka Lokalnych Grup Działania w województwie świętokrzyskim}

Na terytorium woj. świętokrzyskiego aktualnie funkcjonuje 18 LGD², które obejmują swym zasięgiem 120 gmin, w tym 24 spoza regionu (tab. 1). Przeciętnie dla jednej LGD przypada 7 jednostek administracyjnych. Powierzchnia, której dotyczy działalność LGD, stanowi 13,6 tys. $\mathrm{km}^{2}$, a zamieszkana jest przez 991,3 tys. osób. Najstarszą LGD, którą założono w 2001 roku, jest LGD Ziemi Sandomierskiej. Zdecydowana większość z nich (61\%) powstała w 2008 roku. Z kolei największą LGD, zarówno pod względem powierzchni (2,5 tys. km²), jak i liczby ludności (143,7 tys.) jest - istniejąca dopiero od 2015 roku - Świętokrzyska Rybacka LGD (ryc. 1). W jej skład wchodzi łącznie aż 18 gmin położonych w zachodniej części woj. świętokrzyskiego. Są to jednocześnie jednostki, stanowiące zasięg terytorialny innych partnerstw: ze Stowarzyszenia LGD „Ziemia Jędrzejowska - GRYF” - wszystkie 9 gmin; z LGD „Region Włoszczowski” - 5 gmin; z LGD „Nad Czarną i Pilicą” - 3 gminy; ze Stowarzyszenia „LGD

\footnotetext{
${ }^{2}$ Dotyczy LGD, które posiadają siedzibę w gminie należącej do woj. świętokrzyskiego.
} 
- U ŹRÓDEŁ" - 1 gmina. Najmniejszy obszar działania $\left(0,3\right.$ tys. $\left.\mathrm{km}^{2}\right)$ ma LGD „Perły Czarnej Nidy”, skupiając 3 gminy zlokalizowane na południe od Kielc, zamieszkane przez 38,7 tys. osób. Jednak najmniej ludności (34,1 tys.) znajduje się na terenie funkcjonowania LGD Dorzecze Wisły. Dominują LGD, w skład których wchodzą tylko gminy z woj. świętokrzyskiego. Jedynie 5 LGD posiada gminy partnerskie spoza regionu. Gminy te reprezentują w pierwszej kolejności woj. mazowieckie (11), następnie łódzkie (8), małopolskie (4) oraz śląskie (1).

Tabela 1. Lokalne Grupy Działania na terenie woj. świętokrzyskiego w 2017 roku

\begin{tabular}{|c|c|c|c|c|c|c|}
\hline p. & Nazwa LGD & Siedziba LGD & $\begin{array}{c}\text { Rok } \\
\text { założenia } \\
\text { LGD** }\end{array}$ & $\begin{array}{l}\text { Liczba } \\
\text { gmin } \\
\text { objętych } \\
\text { LGD } \\
\text { (spoza } \\
\text { woj.) }\end{array}$ & $\begin{array}{c}\text { Po- } \\
\text { wierzch- } \\
\text { nia objęta } \\
\text { LGD } \\
{\left[\mathrm{km}^{2}\right]}\end{array}$ & $\begin{array}{l}\text { Liczba } \\
\text { miesz- } \\
\text { kań- } \\
\text { ców }\end{array}$ \\
\hline 1. & LGD „Białe Lugi” & $\begin{array}{l}\text { Trzemosna } \\
\text { gm. Daleszyce }\end{array}$ & 2006 & 7 & 1119 & 76264 \\
\hline 2. & LGD „Dorzecze Bobrzy” & $\begin{array}{l}\text { Kostomłoty } \\
\text { Drugie } \\
\text { gm. Miedziana } \\
\text { Góra }\end{array}$ & 2006 & 5 & 408 & 60549 \\
\hline 3. & LGD - Dorzecze Wisły & Połaniec & 2008 & 5 & 466 & 34095 \\
\hline 4. & $\begin{array}{l}\text { LGD „Królewskie Poni- } \\
\text { dzie” }\end{array}$ & Busko-Zdrój & 2007 & 8 & 968 & 72779 \\
\hline 5. & $\begin{array}{l}\text { LGD „Nad Czarną } \\
\text { i Pilicą” }\end{array}$ & Łopuszno & 2008 & 5 & 754 & 36720 \\
\hline 6. & $\begin{array}{l}\text { LGD „Perły Czarnej } \\
\text { Nidy” }\end{array}$ & Morawica & 2008 & 3 & 313 & 38738 \\
\hline 7. & LGD „Perły Ponidzia” & Skalbmierz & 2008 & $8(4)$ & 489 & 35460 \\
\hline 8. & LGD PONIDZIE & Pińczów & 2008 & 5 & 613 & 39838 \\
\hline 9. & $\begin{array}{l}\text { LGD Powiatu Opatow- } \\
\text { skiego }\end{array}$ & Opatów & 2008 & 5 & 629 & 36288 \\
\hline 10. & $\begin{array}{l}\text { LGD „Region Włosz- } \\
\text { czowski” }\end{array}$ & Włoszczowa & 2008 & $11(6)$ & 1448 & 71058 \\
\hline 11. & $\begin{array}{l}\text { LGD Ziemi Sandomier- } \\
\text { skiej }\end{array}$ & Łoniów & 2001 & 9 & 728 & 60230 \\
\hline 12. & $\begin{array}{l}\text { Stowarzyszenie „LGD } \\
\text { - U ŹRÓDEŁ” }\end{array}$ & $\begin{array}{l}\text { Modliszewice } \\
\text { gm. Końskie }\end{array}$ & 2008 & $9(3)$ & 1233 & 89430 \\
\hline 13. & $\begin{array}{l}\text { Stowarzyszenie LGD } \\
\text { „Krzemienny Krąg” }\end{array}$ & Bałtów & 2008 & $9(5)$ & 1064 & 63655 \\
\hline
\end{tabular}


Tabela 1 cd.

\begin{tabular}{|c|c|c|c|c|c|c|}
\hline 14. & $\begin{array}{l}\text { Stowarzyszenie LGD } \\
\text { „Razem na Piaskowcu” }\end{array}$ & $\begin{array}{l}\text { Mirzec Stary } \\
\text { gm. Mirzec }\end{array}$ & 2015 & $8(6)$ & 702 & 58868 \\
\hline 15. & $\begin{array}{l}\text { Stowarzyszenie „LGD } \\
\text { - Wokół Łysej Góry” }\end{array}$ & Bieliny & 2006 & 7 & 636 & 69080 \\
\hline 16. & $\begin{array}{l}\text { Stowarzyszenie LGD } \\
\text { „Ziemia Jędrzejowska } \\
\text { - GRYF” }\end{array}$ & Jędrzejów & 2008 & 9 & 1257 & 86886 \\
\hline 17. & $\begin{array}{l}\text { Stowarzyszenie Rozwoju } \\
\text { Wsi Świętokrzyskiej }\end{array}$ & Łagów & 2008 & 7 & 810 & 61395 \\
\hline 18. & $\begin{array}{l}\text { Świętokrzyska } \\
\text { Rybacka LGD }\end{array}$ & Włoszczowa & 2015 & 18 & 2513 & 143710 \\
\hline \multicolumn{4}{|c|}{ Razem } & $120(24)$ & 13637 & 991333 \\
\hline
\end{tabular}

* Wg wpisu do rejestru stowarzyszeń Krajowego Rejestru Sądowego.

Źródło: opracowanie własne na podstawie bazy danych KSOW 2014-2020, informacji od LGD oraz BDL GUS.

Przestrzeń będąca w zasięgu aktywności świętokrzyskich LGD to praktycznie wszystkie (96) gminy, które mogą być włączane w te kooperacje. Jedynym wyjątkiem jest gmina miejsko-wiejska Kazimierza Wielka, która przynależy do Nadwiślańskiej Grupy Działania „E.O. CENOMA”. Można jeszcze dostrzec jednorodność terytorialną 4 LGD z granicami 4 powiatów, ponieważ odpowiedzialne są za rozwój we wszystkich mieszczących się w nich gminach. Dotyczy ona trzech powiatów regionu Ponidzia, tj. jędrzejowskiego, pińczowskiego, buskiego, a także powiatu sandomierskiego. Pozostałe powiaty są w zasięgu od 2 (np. staszowski, ostrowiecki) do 6 LGD (kielecki $\left.{ }^{3}\right)$.

Jak wspomniano, w szczegółowych badaniach uwzględniono 5 LGD z siedzibą na terenie woj. świętokrzyskiego (ryc. 2). Wszystkie rozpatrywane LGD przybrały formę stowarzyszeń posiadających osobowość prawną. Najwcześniej, w 2006 roku rozpoczęła działalność LGD „Białe Ługi”, rok później - LGD „Perły Ponidzia”, zaś pozostałe zostały zarejestrowane w 2008 roku. Stanowią one razem płaszczyznę partnerstwa dla 452 zdeklarowanych członków, w której ranga poszczególnych sektorów według ich udziałów jest następująca: mieszkańcy (42\% ogółu), sektor społeczny (27,2\%), sektor gospodarczy (18\%) i sektor publiczny (12,6\%) - (tab. 2). Taki stan jest jak najbardziej pożądany, ponieważ im wyższy udział przedstawicieli sektora społecznego oraz mieszkańców w LGD, tym lepsza wiedza dotycząca koniecznych działań w dążeniu do efektywnego rozwoju społeczno-gospodarczego obszarów wiejskich czy aktywizacji i integracji społeczeństwa (Wankiewicz 2009; Czapiewska 2012). Ponadto wybrane LGD

\footnotetext{
${ }^{3} \mathrm{Na}$ jego terenie została zlokalizowana $1 / 3$ siedzib LGD woj. świętokrzyskiego.
} 


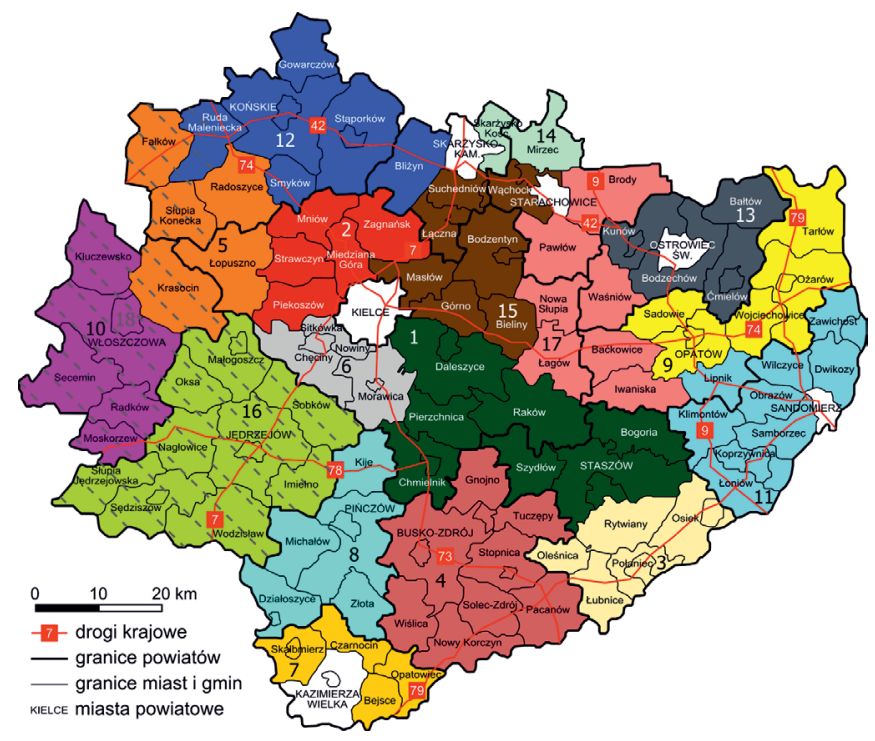

Ryc. 1. Rozmieszczenie Lokalnych Grup Działania na terenie woj. świętokrzyskiego* w 2017 roku

* Numer odzwierciedla porządek LGD zgodnie z tab. 1 i oznacza gminę lokalizacji siedziby danej grupy.

Źródło: opracowanie własne

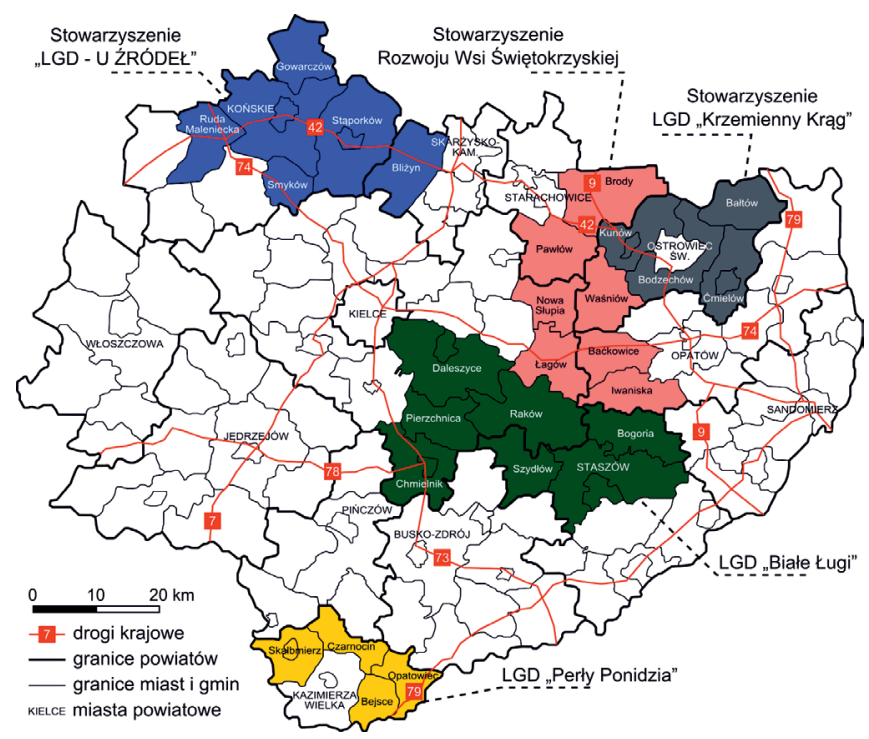

Ryc. 2. Rozmieszczenie wybranych Lokalnych Grup Działania na terenie woj. świętokrzyskiego w 2017 roku Źródło: opracowanie własne 


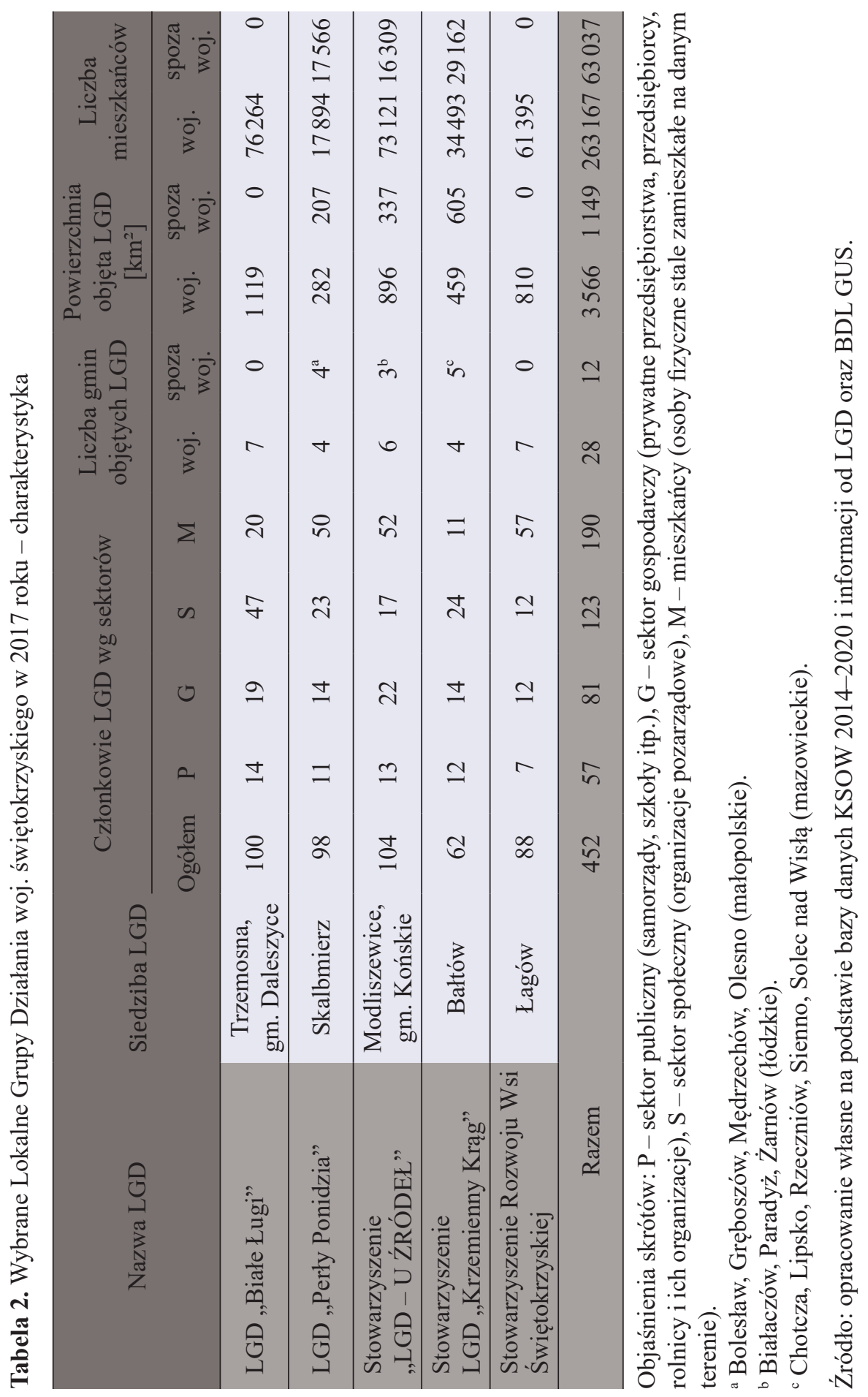


skupiają łącznie 33\% (40) gmin, które są w zasięgu działania świętokrzyskich LGD, a co za tym idzie obejmują 34,6\% (4,7 tys. $\left.\mathrm{km}^{2}\right)$ tegoż obszaru, na którym mieszka ok. 33\% (326,2 tys.) ludności. Przy tym odnośnie 3 LGD („Perły Ponidzia”, „LGD - U ŹRÓDEŁ”, „Krzemienny Krąg”) należy zaznaczyć istnienie w sumie 12 z 24 współpracujących gmin spoza woj. świętokrzyskiego, z terytorium 1,1 tys. $\mathrm{km}^{2}$ i zaludnieniem równym 63 tys. osób. Szczególnie wyróżnia się na tym tle LGD „Krzemienny Krąg”, gdzie większość stowarzyszenia to mazowieckie gminy, o przeważającej powierzchni, ale mniejszym potencjale ludnościowym niż w granicach woj. świętokrzyskiego.

Pierwsza spośród badanych grup działania, Stowarzyszenie „LGD - U ŹRÓDEŁ", położona jest w północnej części województwa. Łączy współpracę 9 gmin głównie powiatu koneckiego. Zasięgiem swym obejmuje powierzchnię ok. 1,2 tys. $\mathrm{km}^{2}$, na której zamieszkuje 89,4 tys. osób. Stowarzyszenie zrzesza największą liczbę członków (104) w badanym zestawieniu. W strukturze członkostwa LGD dominują mieszkańcy (52 przedstawicieli) oraz sektor gospodarczy (22). W przestrzeni objętej przez LGD atutami o wciąż dużym potencjale rozwoju są walory przyrodnicze i turystyczne, czyli lasy sosnowe, wody głębinowe i nieskażone środowisko naturalne, sprzyjające rozwojowi turystyki rekreacyjnej i prozdrowotnej. W inwestycjach w zagospodarowanie turystyczne upatruje się tu roli we wzmocnieniu lokalnej gospodarki.

W północno-wschodniej części regionu znajduje się Stowarzyszenie Rozwoju Wsi Świętokrzyskiej. Skupia ono 7 gmin zlokalizowanych w granicach 4 powiatów województwa (kielecki, starachowicki, opatowski i ostrowiecki), o powierzchni 0,8 tys. $\mathrm{km}^{2}$ i zaludnieniu wynoszącym 61,4 tys. osób. Relacje partnerskie w LGD budowane są w głównej mierze przez mieszkańców (57 przedstawicieli). W zasięgu ich aktywności jest obszar, którego najważniejszymi mocnymi stronami są: połżenie w pobliżu ważnych szlaków komunikacyjnych, bogate zasoby geologiczne i żyzne gleby, walory krajobrazowo-przyrodnicze dla rozwoju turystyki, liczne i cenne zabytki (m.in. Sanktuarium Relikwii Drzewa Krzyża Świętego na Świętym Krzyżu, Zamek Krzyżtopór w Ujeździe), rozwinięty przemysł przetwórstwa mięsnego, drzewnego oraz górnictwa skalnego.

Z opisaną wyżej LGD sąsiaduje od wschodu LGD „Krzemienny Krąg”. Zrzesza ona 9 jednostek terytorialnych, z czego 4 leżą w woj. świętokrzyskim, $\mathrm{w}$ powiecie ostrowieckim. Przestrzenny zasięg działania to 1,06 tys. $\mathrm{km}^{2}$, natomiast potencjał ludnościowy to 63,7 tys. osób. W strukturze członków wiodącą rolę pełnią organizacje pozarządowe (24 przedstawicieli), które stanową prawie $39 \%$ wśród 62 stowarzyszonych podmiotów. To najmniej liczna spośród analizowanych grupa działania. Zalety obszaru, którym się ona zajmuje, to przede wszystkim: walory turystyczne wynikające z lokalizacji, istnienie produktów lokalnych, a także unikatowe dziedzictwo kulturowe (pomnik historii „Krzemionki" - kopalnie krzemienia z epoki neolitu w gminie Bodzechów, koło Ostrowca Świętokrzyskiego). 
W centralnej części woj. świętokrzyskiego położona jest LGD „Białe Ługi”, granicząc od północy ze Stowarzyszeniem Rozwoju Wsi Świętokrzyskiej. Jest największą z badanych grupą działania zarówno pod względem zajmowanej powierzchni (1,12 tys. $\mathrm{km}^{2}$ ), jak i liczby mieszkańców (76,3 tys.). Partnerstwo łączy działaczy 7 gmin z powiatu kieleckiego oraz staszowskiego. Podobnie jak w przypadku LGD „Krzemienny Krąg”, strukturę współpracy zdominowali przedstawiciele sektora społecznego (47 podmiotów). Do mocnych stron terenu LGD „Białe Ługi” należy położenie pomiędzy dużymi miastami - Kielce, Ostrowiec Świętokrzyski, Sandomierz i Busko-Zdrój, co jest korzystne dla rozwoju lokalnej gospodarki. To również różnorodność form ochrony przyrody, lokalne produkty spożywcze i rękodzielnictwo, które są motorem rozwoju turystyki wiejskiej i ekoturystyki. Obok nich występuje bardzo dużo zabytków. Dopełnienie walorów turystycznych tworzą stoki narciarskie, trasy piesze, rowerowe i konne oraz zbiorniki wodne.

Na południu woj. świętokrzyskiego funkcjonuje LGD „Perły Ponidzia” - najmniejsza w świetle rozpatrywanych stowarzyszeń. Obejmuje tylko ok. 0,5 tys. $\mathrm{km}^{2}$ obszaru, zamieszkałego przez 35,5 tys. osób. Połowę gmin przynależących do LGD stanowią jednostki powiatu kazimierskiego. Pod względem udziału członków w grupie przeważają mieszkańcy, w liczbie 50 przedstawicieli, przy czym istotny wkład należy przypisać także organizacjom pozarządowym - 23 podmioty. Jednym z podstawowych atutów obszaru LGD jest jego geograficzne położenie i walory naturalne. Dobry stan środowiska i gleby wysokiej jakości umożliwiają rozwój perspektywicznego rolnictwa ekologicznego. Do tego ożywienie przestrzeni lokalnej wzmacniają zasoby dziedzictwa historyczno-kulturowego i liczne obiekty archeologiczne.

\section{Dofinansowanie LGD w ramach funduszy strukturalnych}

Cele główne, jakie były realizowane przez wybrane LGD w latach 2007-2013, koncentrowały się zwłaszcza na wzmocnieniu potencjału turystycznego. Szczególny nacisk położono na wykorzystanie walorów środowiska przyrodniczego i dziedzictwa kulturowego. Ponadto ukierunkowywano się na umocnieniu poczucia tożsamości mieszkańców poprzez kultywowanie tradycji. Uwzględniono również podniesienie poziomu aktywności społecznej i gospodarczej mieszkańców poprzez rozwój nowoczesnej gospodarki opartej na wiedzy oraz stymulowanie pożądanych procesów społecznych.

Z analizy obszarów tematycznych przedsięwzięć zaplanowanych w LSR w ramach PROW 2007-2013 wynika, że wszystkie rozpatrywane lokalne partnerstwa realizowały zadania $\mathrm{w}$ zakresie rozwoju agroturystyki i turystyki wiejskiej, jak również promocji produktu lokalnego (tab. 3). Na drugim miejscu należy wskazać przedsięwzięcia skoncentrowane na ochronie dziedzictwa kulturowego, poprawie infrastruktury wiejskiej oraz rozwoju przedsiębiorczości. Nieco mniejszy nacisk 
kładziono na działania na rzecz ekologii i ochrony środowiska lub dziedzictwa kulinarnego bądź na wykorzystanie zasobów naturalnych. Tylko LGD „Krzemienny Krąg” miało na celu stymulowanie innowacyjności obszarów w ramach wsparcia nowych technologii i wykorzystania odnawialnych źródeł energii.

Tabela 3. Obszary tematyczne przedsięwzięć zawartych w Lokalnych Strategiach Rozwoju wybranych Lokalnych Grup Działania woj. świętokrzyskiego w latach 2007-2013

\begin{tabular}{|c|c|c|c|c|c|}
\hline \multirow[b]{2}{*}{$\begin{array}{l}\text { Obszary tematyczne } \\
\text { przedsięwzięć }\end{array}$} & \multicolumn{5}{|c|}{ Wybrane LGD } \\
\hline & $\begin{array}{l}\text { LGD } \\
\text { „Białe } \\
\text { Lugi” }\end{array}$ & $\begin{array}{c}\text { LGD } \\
\text { „Perły } \\
\text { Ponidzia” }\end{array}$ & $\begin{array}{l}\text { Stow. } \\
\text { "LGD } \\
\text { - U ŹRÓ- } \\
\text { DEL" }\end{array}$ & $\begin{array}{l}\text { Stow. } \\
\text { LGD } \\
\text { „Krze- } \\
\text { mienny } \\
\text { Krąg” }\end{array}$ & $\begin{array}{l}\text { Stow. } \\
\text { Rozwo- } \\
\text { ju Wsi } \\
\text { Święto- } \\
\text { krzyskiej }\end{array}$ \\
\hline $\begin{array}{l}\text { Agroturystyka i turystyka } \\
\text { wiejska }\end{array}$ & & & & & \\
\hline $\begin{array}{l}\text { Promocja produktu } \\
\text { lokalnego }\end{array}$ & & & & & \\
\hline $\begin{array}{l}\text { Ochrona dziedzictwa } \\
\text { kulturowego }\end{array}$ & & & & & \\
\hline $\begin{array}{l}\text { Poprawa infrastruktury } \\
\text { wiejskiej }\end{array}$ & & & & & \\
\hline $\begin{array}{l}\text { Rozwój } \\
\text { przedsiębiorczości }\end{array}$ & & & & & \\
\hline $\begin{array}{l}\text { Ekologia i ochrona } \\
\text { środowiska }\end{array}$ & & & & & \\
\hline $\begin{array}{l}\text { Ochrona dziedzictwa } \\
\text { kulinarnego }\end{array}$ & & & & & \\
\hline $\begin{array}{l}\text { Wykorzystanie zasobów } \\
\text { naturalnych }\end{array}$ & & & & & \\
\hline $\begin{array}{l}\text { Wsparcie nowych } \\
\text { technologii }\end{array}$ & & & & & \\
\hline Wykorzystanie OZE & & & & & \\
\hline
\end{tabular}

Źródło: opracowanie własne na podstawie LSR objętych PROW 2007-2013 i danych udostępnianych przez LGD.

Poziom dofinansowania odpowiednich projektów realizowanych przez beneficjentów w ramach wdrażania LSR musiał zgadzać się z warunkami określonymi w PROW 2007-2013 na działania w zakresie odnowy wsi, rozwoju działalności pozarolniczej, tworzenia i rozwoju mikroprzedsiębiorstw oraz na tzw. „,małe projekty”. W przypadku działań: „Różnicowanie w kierunku działalności nierol- 
niczej” i „Tworzenie i rozwój mikroprzedsiębiorstw” maksymalny poziom dofinansowania wynosił 50\%. Dla każdego z wchodzących w nie projektów również określono maksymalne kwoty wsparcia. Pomoc na „Różnicowanie w kierunku działalności nierolniczej” wynosiła co najwyżej 100 tys. zł dla pojedynczego beneficjenta na czas realizacji programu. Dla operacji „Tworzenie i rozwój mikroprzedsiębiorstw" miały miejsce 3 progi dofinansowania:

- 100 tys. zł w przypadku utworzenia 1 lub 2 miejsc pracy,

- 200 tys. zł dla 2 i mniej niż 5 miejsc pracy,

- 300 tys. zł dla co najmniej 5 miejsc pracy.

Powstanie danego miejsca pracy musiało odpowiadać zakresowi rzeczowemu projektu. Z kolei działanie „Odnowa i rozwój wsi” związane było ze wsparciem finansowym sięgającym maksymalnie 500 tys. zł na projekty realizowane $\mathrm{w}$ jednej miejscowości. W przypadku małych projektów dany beneficjent mógł otrzymać do 100 tys. zł, lecz nie więcej niż 25 tys. zł na pojedynczy projekt. Zakres małych projektów obejmował m.in. podnoszenie świadomości i rozwijanie aktywności społecznej mieszkańców, rozwój turystyki lub rekreacji, zachowanie lokalnego dziedzictwa kulturowego i historycznego, produkcję i wykorzystanie energii ze źródeł odnawialnych (Budowanie... 2008).

Łączny budżet badanych LGD woj. świętokrzyskiego na wdrażanie LSR wyniósł 43,5 mln zł (tab. 4). Największą kwotę przeznaczono na operacje „Odnowa i rozwój wsi" - ok. $25 \mathrm{mln}$ zł (57,3\% ogółu), natomiast najmniejszą na „Różnicowanie w kierunku działalności nierolniczej” - 1,3 mln zł (3\%). Jeśli chodzi o poszczególne stowarzyszenia, to dominującym budżetem odznaczyła się LGD „Białe Lugi” (12,5 mln zł, tj. ok. 28,8\% z 43,5 mln zł). Z drugiej strony najniższy budżet dotyczył LGD „Perły Ponidzia” (5,5 mln zł, tj. 12,7\% sumy). W pozostałych trzech grupach budżet wyniósł średnio $8,5 \mathrm{mln}$ zł. Nie stwierdzono jednej wiodącej grupy analizowanego zestawienia w strukturze wydatkowania według poszczególnych działań wdrażających LSR. Zatem na dofinansowanie działań „Różnicowanie w kierunku działalności nierolniczej” najwięcej środków przeznaczyła LGD „Perły Ponidzia” - 0,4 mln zł. W przypadku „Tworzenia i rozwoju mikroprzedsiębiorstw" ponad $2 \mathrm{mln}$ zł poświęciło Stowarzyszenie „LGD - U ŹRÓDEŁ”. Na „Odnowę i rozwój wsi” średnio dwukrotnie wyższa kwota od pozostałych LGD - 8,7 mln zł - została wydana przez LGD „Białe Ługi”. Była to jednocześnie zdecydowanie największa część porównywanych budżetów. Maksymalne finansowanie „Małych projektów” (3,3 mln zł) osiągnęła LGD „Krzemienny Krąg”. Warto zaznaczyć, że przeciętny odsetek wydatkowanych kwot budżetów na realizację LSR w minionej perspektywie wyniósł ponad $92 \%{ }^{4}$.

${ }^{4} \mathrm{Na}$ podstawie raportów zamieszczonych w SRLKS objętych PROW 2014-2020 i danych udostępnianych przez LGD. 


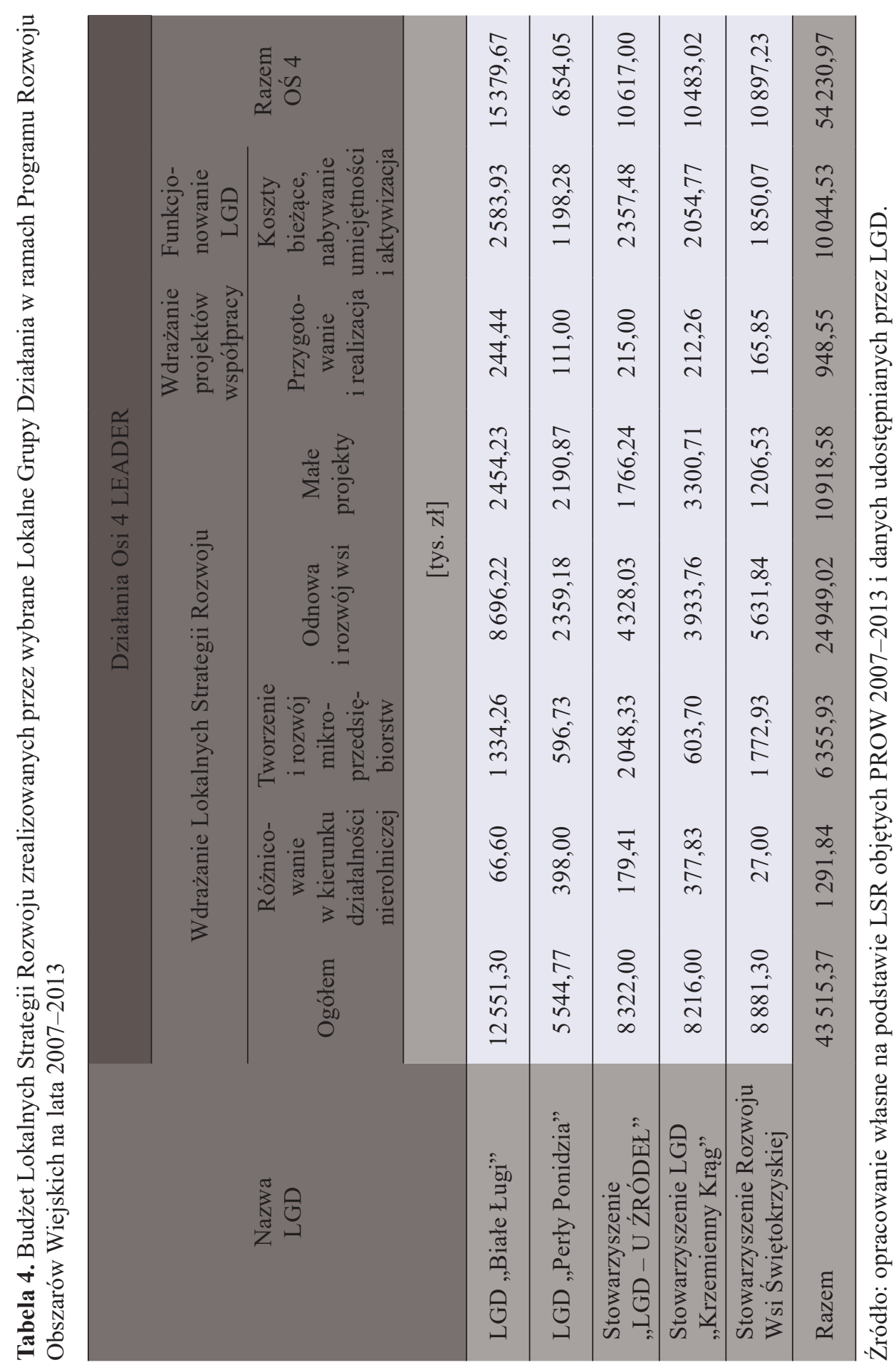


Oprócz działań wdrażających LSR wśród działań Osi 4 LEADER LGD posiadały środki na „Wdrażanie projektów współpracy” oraz funkcjonowanie stowarzyszenia. W badanym zbiorze przygotowanie i realizacja partnerskich przedsięwzięć pochłonęła ok. 0,95 mln zł, w tym najwięcej w LGD „Białe Ługi” (25,8\% łącznej kwoty). Wszystkie koszty bieżące, szkolenia itp. wyniosły ponad $10 \mathrm{mln}$ zł, w tym stanowiły maksimum również we wskazanej LGD $(25,7 \%)$. Ponadto stowarzyszenie to wykonało $\mathrm{w}$ ramach Osi 4 najwięcej budżetu $(15,4 \mathrm{mln})$, tzn. $28,4 \%$ z $54,2 \mathrm{mln}$ zł.

Środki finansowe wspierały rozwój różnych projektów organizowanych na obszarze funkcjonowania określonych LGD. W pracy zwrócono uwagę na te realizacje dokonane w latach 2007-2013, które łączyły wysiłek kilku LGD. W pierwszej kolejności należy dostrzec projekt partnerski, liniowy produkt turystyczny „Szlak Przygody”. Współpracowały przy jego powstawaniu m.in. trzy badane i sąsiadujące ze sobą LGD: Stowarzyszenie Rozwoju Wsi Świętokrzyskiej, „Białe Ługi”, „Krzemienny Krąg”. Wytyczony na ich terenie szlak podzielony jest obecnie na 8 tematycznych Krain: „Talentów”, „Sacrum i Profanum”, „Legend”, „Natury”, „Trzech Rzek”, „Czterech Żywiołów”, „Kultur”, a także „Kraina Świętokrzyskie Poza Szlakiem". W skład krain wchodzi wiele ciekawych, cennych obiektów, np.: Dworek Sienkiewicza w Oblęgorku, Pałac w Kurozwękach, Opactwo Cystersów w Wąchocku, Sanktuarium na Świętym Krzyżu, Muzeum Porcelany w Ćmielowie. Zasięg „Szlaku Przygody” to ok. $900 \mathrm{~km}$ tras, które łączą ponad 100 odpowiednio oznakowanych atrakcji turystycznych. To oryginalna inicjatywa, mająca na celu zapoznanie turystów oraz mieszkańców województwa z bogactwem Ziemi Świętokrzyskiej. Projekt powstał w 2013 roku i wówczas otrzymał tytuł Najlepszego Produktu Turystycznego Roku. Opinie użytkowników zamieszczone na portalach tematycznych wskazują na wartość tego partnerskiego produktu turystycznego:

Nawet nie wiedziałam, że mamy tyle fajnych miejsc $w$ regionie. Odwiedzę teraz wszystkie ${ }^{5}$; Byłam w maju, akurat trafiłam na paskudną pogodę, ale to nie przeszkodziło mi pozwiedzać. Piękne miejsca, wspaniała przyroda. Muszę tu jeszcze przyjechać6.

Niestety, zauważalny jest $\mathrm{w}$ tej chwili brak kontynuacji promocji opisanego projektu, co może być następstwem przerwania ciągłości finansowania bądź skoncentrowaniem się LGD na innych aspektach rozwoju lokalnego.

Kolejny bardzo ważny przykład to przedsięwzięcie powstałe przy współpracy międzynarodowej pt. „Śliwkowy Obszar Turystyczny” (Plum Area Tourism - PAT). Partnerem krajowym projektu była LGD „Białe Ługi”, koordynatorem - Stowarzyszenie „Na Śliwkowym Szlaku” (woj. świętokrzyskie), zaś partnerami zagranicznymi słowacka LGD „Bachuren” oraz węgierska LGD „Cserhátalja”. Projekt uzyskał pomoc w latach 2012-2013. Poprzez działania związane z PAT

\footnotetext{
${ }^{5}$ http://www.szlakprzygody.eu (dostęp: 10.12.2017).

${ }^{6} \mathrm{https}$ ://www.polskieszlaki.pl/swietokrzyski-szlak-przygody.htm (dostęp: 10.12.2017).
} 
miano na celu skuteczną promocję walorów turystycznych, kulturowych i gastronomicznych. Dlatego zasadniczym dążeniem było ustanowienie produktu turystycznego związanego ze śliwką, jako wspólnym elementem obszarów działania LGD, które posiadają wiekowe tradycje związane z hodowlą i jej przetwórstwem? Jednym $\mathrm{z}$ wielu wypromowanych śliwkowych produktów jest śliwka wędzona ze świętokrzyskiej gminy Szydłów (obszar LGD „Białe Ługi”), na terenie której jest produkowanych 30 odmian owocu. Wspomniana odmiana wytwarzana jest tradycyjnie w sposób unikalny na tzw. laskach, a przez to została zarejestrowana jako produkt tradycyjny Ministerstwa Rolnictwa i Rozwoju Wsi pod nazwą Śliwka Szydłowska (Spacerem... 2012).

W innym projekcie partnerskim o kulinarnym charakterze uczestniczyła badana LGD „Perły Ponidzia”. Na obszarze odpowiedzialności trzech LGD łączących 10 gmin świętokrzyskich i 4 małopolskie założono powstanie nowego markowego produktu - „Kulinarnego Szlaku” - przeprowadzając w okresie 2012-2013 projekt „Festiwal Smaków”. Jego cele były następujące: identyfikacja oraz promocja na rynku produktów lub potraw wytwarzanych tradycyjnymi metodami, będących częścią dziedzictwa kulinarnego regionu i elementem tożsamości mieszkańców; uzupełnienie oferty turystycznej pod kątem żywieniowym poprzez oznakowany „Szlak Kulinarny”; wzrost poziomu integracji lokalnych środowisk sektora turystyki poprzez zaangażowanie w organizacje cyklicznych kiermaszów produktów tradycyjnych, regionalnych i rękodzieła; aktywizacja społeczności wchodzącej w skład „Szlaku Kulinarnego” poprzez zawiązanie sieci sklepików czy restauracji, która umożliwi jej przedstawicielom wspólną promocję siebie i zmaterializowanie idei, jaką stanowi uznana już ogólnopolska Sieć „Nasze Kulinarne Dziedzictwo"s. Jednym z rezultatów tych działań była też książka kucharska pt. Pamiętnik kulinarny Ponidzia i Powiśla (2013), za pośrednictwem której autorzy zachęcają do pielęgnowania tradycji kuchni polskiej i regionalnej przez korzystanie z zamieszczonych $\mathrm{w}$ niej przepisów.

Warto wyróżnić jeszcze jedną operację z terenu analizowanych grup działania. Był to regionalny projekt sfinalizowany w 2014 roku - „Aktywna Turystyka i Wypoczynek” (AKTIW), który połączył kooperacją Stowarzyszenie „LGD - U ŹRÓDEŁ” wraz z LGD „Region Włoszczowski”. Dzięki temu powstało pięć certyfikowanych parków do Nordic Walking, z czego dwa na Ziemi Koneckiej - jeden zlokalizowano w gminie Ruda Maleniecka (30 km tras), a drugi w gminie Bliżyn (ok. $29 \mathrm{~km}$ ). Łącznie oba parki mogą przyciągać mieszkańców i turystów do tej formy aktywności w ramach 6 tras o różnych długościach, tj. od 2,6 km do 15,8 km (Działania... 2015). W perspektywie PROW 2014-2020 stowarzyszenie będzie kontynuować rozwój tej infrastruktury turystycznej i rekreacyjnej, aby wszystkie gminy na danym obszarze posiadały własny park Nordic Walking.

\footnotetext{
${ }^{7} \mathrm{http}: / /$ theplum.eu (dostęp: 10.12.2017).

${ }^{8} \mathrm{http}: / /$ festiwalsmakow.cba.pl (dostęp: 10.12.2017).
} 
Bieżąca perspektywa rozwoju lokalnego przestrzeni aktywowanych przez 5 rozpatrywanych LGD oparta jest na 4 zakresach wsparcia finansowego zgodnie z PROW 2014-2020 (tab. 5). Jednym z nich jest „Wdrażanie SRLKS”, który analogicznie do poprzedniego okresu stanowi największy odsetek budżetów LGD - w sumie 37,6 mln zł, tj. 78,3\% z kwoty ogółem 48,1 mln zł. Generalnie dla wszystkich LGD, za wyjątkiem LGD „Perły Ponidzia”, ustalono łączne wsparcie W wysokości przekraczającej $10 \mathrm{mln}$ zł. Należy przy tym podkreślić, że nadal wzmacnia się świadomość roli wpływu społeczności lokalnych na charakter i kierunek rozwoju danego obszaru.

Tabela 5. Budżet Strategii Rozwoju Lokalnego Kierowanego przez Społeczność realizowanych przez wybrane Lokalne Grupy Działania w ramach Programu Rozwoju Obszarów Wiejskich na lata 2014-2020

\begin{tabular}{lrrrrr} 
& \multicolumn{5}{c}{ Zakres wsparcia finansowego PROW } \\
\cline { 2 - 6 } \multicolumn{1}{c}{ Nazwa LGD } & $\begin{array}{c}\text { Wdrażanie } \\
\text { SRLKS }\end{array}$ & Współpraca Aktywizacja & $\begin{array}{c}\text { Koszty } \\
\text { bieżące }\end{array}$ & Ogółem \\
\cline { 2 - 6 } & \multicolumn{5}{c}{ [tys. zł] } \\
\hline LGD „Białe Ługi” & 8550,00 & 427,50 & 90,00 & 1857,50 & 10925,00 \\
\hline LGD „Perly Ponidzia” & 4500,00 & 90,00 & 30,00 & 1095,00 & 5715,00 \\
\hline $\begin{array}{l}\text { Stowarzyszenie } \\
\text { „LGD - U ŹRÓDEL” }\end{array}$ & 8550,00 & 427,50 & 100,00 & 1847,50 & 10925,00 \\
\hline $\begin{array}{l}\text { Stowarzyszenie LGD } \\
\text { „Krzemienny Krąg” }\end{array}$ & 8000,00 & 400,00 & 100,00 & 1750,00 & 10250,00 \\
\hline $\begin{array}{l}\text { Stowarzyszenie Rozwoju } \\
\text { Wsi Świętokrzyskiej }\end{array}$ & 8000,00 & 400,00 & 100,00 & 1750,00 & 10250,00 \\
\hline Razem & 37600,00 & 1745,00 & 420,00 & 8300,00 & 48065,00 \\
\hline
\end{tabular}

Źródło: opracowanie własne na podstawie SRLKS objętych PROW 2014-2020 i danych udostępnianych przez LGD.

\section{Aktywność społeczna w ramach LGD - wyniki badań}

Zgodnie z powyższym, pierwszoplanowym celem funkcjonowania jakichkolwiek LGD jest coraz większe zaangażowanie lokalnej ludności wiejskiej we wspólne przedsięwzięcia. Wpisuje się w to m.in. kreowanie lokalnych liderów, odpornych na niepowodzenia, którzy mają zdolność efektywnej aktywizacji społeczności lokalnej, skutecznie pobudzając ją do działania w różnych sferach życia. Stymulowanie inicjatyw tej części społeczeństwa może odbywać się poprzez: organizowanie spotkań tematycznych w obiektach użyteczności publicznej, regularne doskonalenie kompetencji liderów, różnorodne formy wsparcia organizacji pozarządowych. 
Dokonując przeglądu aktywności na rzecz społeczności lokalnej obszarów wiejskich należących do 5 rozpatrywanych LGD, posłużono się portalem Facebook. Stwierdzono, że za jego pośrednictwem swoją działalność w formie strony profilowej promują 4 grupy. Jedynie LGD „Perły Ponidzia” nie posiada wskazanej formy przekazu.

W latach 2014-2017 najwyższym poziomem aktywności odznaczyła się LGD „Krzemienny Krąg”. Przez inicjatywę popularyzowane są różne formy operatywności mieszkańców. Jednym z najnowszych jest projekt grantowy pt. „Aktywnie z rowerem na terenie Krzemiennego Kręgu". Od kilku lat widoczna jest współpraca animatorów krajowych Ośrodków Wsparcia Ekonomii Społecznej z przedstawicielami LGD, którzy spotkali się dotąd po raz trzeci w Bałtowie. Odbyło się także na terenie wyróżnionej LGD „Ogólnopolskie branżowo-tematyczne spotkanie sieciujące dla pracowników zaangażowanych w proces wsparcia istniejących przedsiębiorstw społecznych: doradców biznesowych, pracowników monitorujących PES i PS, konsultantów regionalnych ds. zamówień publicznych". Poza wzmacnianiem przedsiębiorczości organizowane są liczne plenerowe warsztaty animacyjne i wyjazdy studyjne (np. do Cieszyna). LGD „Krzemienny Krąg” wspólnie ze Stowarzyszeniem „Kawaleria” z Toporzyska i Fundacją „MiLA” z Krakowa przeprowadziło na terenie kilku gmin woj. świętokrzyskiego przedsięwzięcie „Młodzieżowe Rady - edukacja obywatelska w praktyce”, obejmujące warsztaty dla młodzieżowych radnych, konkurs na młodzieżowe inicjatywy obywatelskie, realizacje inicjatyw oraz spotkania rad młodzieżowych.

Stowarzyszenie LGD „Białe Ługi” cechuje się także zróżnicowaną formą aktywności na rzecz społeczności wiejskiej, którą prezentuje na portalu społecznościowym. Należy wymienić organizowanie licznych warsztatów podejmujących aktywizację na szczeblach społecznym, zawodowym i gospodarczym, jak np. spotkanie osób młodych do 35. roku życia (wg SRLKS jest to grupa defaworyzowana). Kolejnym przejawem jest sfinalizowanie kilkudziesięciu umów na rozpoczęcie działalności gospodarczej z uczestnikami projektu „LGD-owskie wsparcie w biznesowym starcie". To także realizowane projekty grantowe na organizacje przez samych mieszkańców lokalnych imprez, m.in. „Od pola do Opola”, „Biesiada Miodowa”. Nie brakuje również informacji na temat konkursów, które mają choćby na celu włączenie ludności do inwentaryzacji zasobów występujących na obszarze LGD. Dodatkowo promowane są: szkolenia w zakresie działalności gospodarczej, konkursy (np. kulinarny - pt. „Smak Gęsiny”), wycieczki i wyjazdy studyjne (np. do wzorcowych zagród edukacyjnych na Lubelszczyźnie).

Kolejna grupa działania - Stowarzyszenie Rozwoju Wsi Świętokrzyskiej - posiada duży repertuar mobilizacji mieszkańców wsi. W ostatnim czasie duży nacisk położono na promocję przestrzeni lokalnej w obszarze turystyki. Przykładem jest zorganizowanie konferencji dla przedstawicieli biur podróży z całego kraju na temat „Góry Świętokrzyskie wczoraj, dziś, jutro...”. Cyklicznym przedsięwzięciem stały się zajęcia z języka angielskiego dla dzieci, począwszy 
od edukacji przedszkolnej do gimnazjalnej, jak również warsztaty szkoleniowe lub konkursy dla młodzieży nawiązujące do dziedzictwa kulturowego. Te ostatnie służą wzmocnieniu więzi społecznych, związanych z kultywowaniem lokalnych zwyczajów oraz tradycji. Umożliwiały to zwłaszcza organizowane wydarzenia kulturalno-rekreacyjne promujące obszar objęty SRLKS, a także wspierane inicjatywy służące kształtowaniu postaw przedsiębiorczych i innowacyjnych.

W świetle udostępnionych za pośrednictwem portalu Facebook informacji, ze strony Stowarzyszenia „LGD - U ŹRÓDEŁ” odnotowano niestety bardzo niski poziom aktywności. Grupa działania wskazywała jedynie na możliwość uczestnictwa w cyklu szkoleń dla mikroprzedsiębiorstw. Dołączono również zasady naboru do projektu „LGD-owskie wsparcie w biznesowym starcie” oraz wytyczne do wniosków o przyznanie pomocy w ramach przedsięwzięcia infrastruktura turystyczna, rekreacyjna i/lub kulturowa.

\section{Podsumowanie}

Lokalne inicjatywy stanowią dużą szansę w rozwoju obszarów wiejskich. Jedną $\mathrm{z}$ wielu ewentualnych form są LGD. Jako partnerstwa publiczno-prywatne, bez czynnika społecznego, nie miałyby szansy istnienia. Przedsięwzięcia prowadzone przez te zrzeszenia mają szczególne znaczenie we wzmacnianiu aktywności i zaangażowaniu mieszkańców wsi w rozwój lokalny. Ta „oddolna droga rozwoju" zyskała na znaczeniu od momentu pojawienia się samodzielnych struktur samorządowych, które zaczęly pełnić rolę realnego gospodarza danego obszaru.

W woj. świętokrzyskim funkcjonuje wiele inicjatyw obywatelskich, które biorą czynny udział w rozwiązywaniu problemów społeczno-gospodarczych. Badane aspekty aktywności wybranych LGD wskazały na zróżnicowany jej charakter. Największe zaangażowanie poszczególnych podmiotów, współpracujących w ramach LGD, stwierdzono w LGD „Krzemienny Krąg”. Przejawy tej aktywności były widoczne w różnych i częstych formach działań. Ukierunkowane zostały na wzrost kompetencji kapitału ludzkiego. W szczególności uzewnętrzniły się w różnego rodzaju szkoleniach, warsztatach aktywizujących tzw. grupy defaworyzowane. Nie bez znaczenia była tu aktywna postawa osób będących liderami kierowanej grupy. Świadczy o tym choćby największa na tle analizowanych LGD promocja przedsięwzięć na portalu społecznościowym. Należy zauważyć, że duży nacisk w ramach realizacji projektów położono na podkreślenie i wykorzystanie walorów krajobrazowo-przyrodniczych, z uwzględnieniem unikatowego dziedzictwa kulturowego. Nawiązanie do tradycji oraz zasobów lokalnych, jakie posiadają obszary wiejskie, jest w perspektywie pierwszoplanową oznaką ich dalszego rozwoju. Fakt ten podkreśla w swoich rozważaniach M. Wójcik (2013): „Dziedzictwo przeszłości, które udało się jeszcze uratować i zachować, w skansenach lub swych pierwotnych lokalizacjach, będzie formą promocji wsi. Miejsca te przestaną pełnić tylko funkcje muzealne i staną się ,żywymi” przestrzeniami 
spotkań z tradycją. W połowie XXI wieku wieś przestanie byś określeniem wstydliwym, a wiejskość będzie oparciem dla alternatywnych modeli rozwoju społeczno-kulturowego".

$\mathrm{Z}$ drugiej strony bardzo słaba aktywność, zaobserwowana na przykładzie Stowarzyszenia „LGD - U ŹRÓDEŁ”, wynika - zdaniem autorów - z niedostatecznej promocji zasobów lokalnych. Jest to obszar o dużych predyspozycjach do rozwoju turystyki. Nie zauważa się jednak odpowiedniego wykorzystania jego potencjału poprzez angażowanie do organizowania przedsięwzięć mających na celu „ożywienie” produktów turystycznych występujących na tym terenie. Dalszym kierunkiem działań tej grupy winno być większe zaangażowanie członków w propagowanie inicjatyw popularyzujących zasoby lokalne.

\section{Literatura}

Budowanie lokalnej strategii rozwoju w ramach osi 4 Leader Programu Rozwoju Obszarów Wiejskich na lata 2007-2013, 2008, Ministerstwo Rolnictwa i Rozwoju Wsi, Warszawa.

Czapiewska G., 2012, Lokalne Grupy Działania a kreowanie rozwoju regionalnego $w$ województwach pomorskim i zachodniopomorskim, „Nierówności Społeczne a Wzrost Gospodarczy", 29: 261-272.

Działania, które wsparly rozwój wsi. Przykłady wykorzystania funduszy PROW na lata 2007-2013 na obszarze działania ,LGD - U ŹRÓDEE”, 2015, Stowarzyszenie „Lokalna Grupa Działania - U ŹRÓDEŁ”, Kwidzyn.

Jeziorska-Biel P., 2014, Odnowa wsi w gminie Nowosolna w województwie tódzkim, [w:] Psyk-Piotrowska E. (red.), Nowe mechanizmy rozwoju obszarów wiejskich, Wydawnictwo Uniwersytetu Łódzkiego, Łódź: 118-141.

Kamiński R., 2006, Konieczność stosowania metody LEADER w nowym funduszu wiejskim - szansa czy zagrożenie?, [w:] Wilkin J., Błąd M., Klepacka D. (red.), Polska strategia w procesie ksztaltowania polityki Unii Europejskiej wobec obszarów wiejskich i rolnictwa, IRWiR PAN, Warszawa: 43-59.

Kołodziejczak A., 2011, Lokalne Grupy Dziatania jako czynnik rozwoju wiejskich obszarów peryferyjnych $w$ województwach lubelskim i podlaskim, „Studia Obszarów Wiejskich", 26: 203-215.

Pałka E., 2014, Rola lokalnych grup działania w rozwoju obszarów wiejskich. Przykład województwa świętokrzyskiego, „Studia i Materiały. Miscellanea Oeconomicae”, 3: 186-203.

Program Rozwoju Obszarów Wiejskich na lata 2014-2020, 2014, MRiRW, Warszawa.

Przybyszewski H. (red.), 2013, Pamiętnik kulinarny Ponidzia i Powiśla, Kazimierska Agencja Drukarska, Kazimierza Wielka.

Spacerem po Polsce. Przewodnik „Białe Ługi”, 2012, Lokalna Grupa Działania „Białe Ługi”, Daleszyce, http://bialelugi.pl/data/file/DNA/Folder.pdf.

Wankiewicz B., 2009, Innowacyjne rozwiazania w zakresie oddziaływania zasobów finansowych gmin na rozwój samorząności, ,Zeszyty Naukowe Uniwersytetu Szczecińskiego. Ekonomiczne Problemy Usług", 31: 160-169. 
Aktywność społeczności wiejskiej w ramach funkcjonowania Lokalnych Grup Działania... 107

Wójcik M., 2010, Struktura i działanie - społeczno-geograficzna interpretacja oddziatywania funduszy Unii Europejskiej na przykładzie programu ,Odnowa Wsi”, ,Studia Obszarów Wiejskich", 24: 186-201.

Wójcik M., 2013, Wieś 2050 - refleksje na temat przyszłości wsi polskiej, ze szczególnym uwzględnieniem regionu łódzkiego, ,Studia Obszarów Wiejskich”, 31: 39-52.

\title{
Źródła internetowe
}

https://bdl.stat.gov.pl/BDL/start (dostęp: 10.09.2017).

http://festiwalsmakow.cba.pl (dostęp: 10.12.2017).

http://theplum.eu (dostęp: 10.12.2017).

https://web.facebook.com (dostęp: 29.12.2017).

https://www.polskieszlaki.pl/swietokrzyski-szlak-przygody.htm (dostęp: 10.12.2017).

http://www.szlakprzygody.eu (dostęp: 10.12.2017).

\section{ACTIVITY OF RURAL COMMUNITY WITHIN FUNCTIONING OF LOCAL ACTION GROUPS IN THE ŚWIĘTOKRZYSKIE VOIVODESHIP}

\begin{abstract}
Development of rural areas is largely affected by NGOs and local organization, a good example of which is the operation of Local Action Groups (LAGs). LAGs mainly stimulate development of rural areas by defining community needs. The goal of this study was to evaluate the activity of inhabitants of rural areas in the Świętokrzyskie Voivodeship within the scope of initiatives of selected LAGs. The study was based on secondary sources with queries of available information: documents of organizations, strategies, data obtained from the Central Statistical Office of Poland, database of the National Rural Network 2014-2020. Social activity was studied on the basis of information concerning finished projects from the period of 2014-2017 published on Facebook by LAGs in question. The time span comprised the period of 2007-2017. The study focused on 5 LAGs headquartered in the Świętokrzyskie Voivodeship and located in its various parts. The areas of their activity are diversified in terms of environmental conditions and economic functions.
\end{abstract}

Keywords: Local Action Groups, rural areas, social activity, advantages of natural environment, tourist potential, historical heritage.

Dr Patryk Brambert

Zakład Badań Regionalnych i Gospodarki Przestrzennej

Instytut Geografii

Wydział Matematyczno-Przyrodniczy

Uniwersytet Jana Kochanowskiego w Kielcach e-mail: patryk.brambert@ujk.edu.pl

Dr Iwona Kiniorska

Zakład Geografii Społeczno-Ekonomicznej

Instytut Geografii

Wydział Matematyczno-Przyrodniczy

Uniwersytet Jana Kochanowskiego w Kielcach e-mail: iwona.kiniorska@ujk.edu.pl 